\title{
PROZODIJSKI MEĐUJEZIK: ISTRAŽIVANJE NA KORPUSU FRANCUSKIH I SRPSKIH PROSTIH IZJAVNIH REČENICA ${ }^{1}$
}

U ovom radu govorićemo o fenomenu prenošenja prozodijskih karakteristika maternjeg (srpskog) u prozodijski kôd stranog jezika (francuski). Preslikavanje akcenatskih i ritmičkih osobenosti srpskog u francuski jezik, u dosadašnjim kontrastivnim istraživanjima na polju prozodije ova dva jezika, poznato je pod nazivom međujezička permeabilnost. Ovu pojavu nastojaćemo da prikažemo i objasnimo u svetlu eksperimentalnog istraživanja koje smo izvršili u računarskom softveru za analizu govora PRAAT na manjem korpusu francuskih i srpskih prostih izjavnih rečenica. U ovom kontekstu, ukratko ćemo govoriti i o akcentu i o karakteristikama ritmičkog uređenja francuskog, odnosno srpskog jezika, kao i o prozodiji francuske i srpske proste izjavne rečenice.

Ključne reči: međujezička permeabilnost, ritmička grupa, akcenatska celina, francuski jezik, srpski jezik.

\footnotetext{
*_joliepuce11@yahoo.fr

1 Korpus rečenica, grafikoni njihovih melodijskih krivulja i ostali rezultati eksperimentalnih merenja koje ćemo ovde analizirati preuzeti su iz šireg korpusa izjavnih, upitnih i uzvičnih rečenica obrađenih u našoj doktorskoj disertaciji ,Ritam i intonacija $u$ francuskom jeziku. Predlog modela za korigovanje grešaka na polju prozodije francuskog jezika kod srbofonih studenata“, odbranjenoj 22. oktobra 2014. godine na Filološkom fakultetu u Beogradu.
} 


\section{Uvod}

Pre nego što počnemo analizu rezultata eksperimentalnog merenja koje smo izvršili na korpusu francuskih prostih izjavnih rečenica i njihovih prevoda na srpski jezik, predstavićemo polazne hipoteze našeg rada koje smo preuzeli iz opšte prihvaćenih teorija na polju prozodije francuskog i srpskog jezika, kao i iz dosadašnjih kontrastivnih istraživanja francuske i srpske prozodije.

Tako ćemo, u cilju tumačenja dobijenih rezultata, ukratko definisati za nas relevantne prozodijske pojmove, kao što su akcenat grupe i ritmička grupa u francuskom jeziku, akcenat i akcenatska celina u srpskom jeziku i prozodijske karatkteristike proste izjavne rečenice u oba jezika.

$\mathrm{S}$ druge strane, a u vezi sa dosadašnjim pionirskim kontrastivnim istraživanjima na polju francuske i srpske prozodije, govorićemo o Šotrinim zaključcima o prvoj i drugoj permeabilnosti (Šotra, 2006: 121-133), od izuzetnog značaja za naše istraživanje koje bi trebalo da predstavlja skroman doprinos prethodnom i da potvrdi da je kod srbofonih studenata francuskog jezika prenošenje akcenatskih i ritmičkih karakteristika srpskog jezika u francuski zaista veoma izraženo.

Potom ćemo predstaviti kraći korpus na kojem smo izvršili eksperimentalno istraživanje, kao i ispitanike koji su učestvovali u snimanju korpusa.

Kako smo istraživanje sproveli analizom audio snimaka u računarskom programu za analizu govora PRAAT, ukratko ćemo definisati za nas izuzetno značajne pojmove kao što su osnovna frekvencija $\mathrm{F}_{0}$ (izražena $\mathrm{u}$ $\mathrm{Hz}$ ) i trajanje (izraženo u sekundama), objašnjavajući pritom od čega se sastoje grafikoni dobijeni u navedenom softveru što bi trebalo da pojednostavi njihovo sagledavanje, tumačenje i razumevanje.

\section{Akcenat i ritam u francuskom jeziku i intonacija proste izjavne rečenice}

Kada su u pitanju akustičke karaktersitike francuskog akcenta, ovde je izuzetno važno naglasiti da u francuskom jeziku na naglašenom slogu u odnosu na nenaglešni slog nema značajnijeg variranja osnovne frekvencije $\mathrm{F}_{0}(H z)$, kao ni intenziteta $(d B)$ koje bi predstavljalo dovoljno jak akcenatski signal, tj. koje bi samosatalno doprinosilo realizaciji akcenta. 
Najvažniji akustički parametar koji se, na naglašenom slogu, istovremeno javlja sa navedenim neznatnim varijacijama osnovne frekvencije i intenziteta, a koji je, u najvećoj meri, odgovaran za realizaciju i percipiranje francuskog akcenta jeste trajanje.

U prilog tome možemo navesti rezultate eksperimentalnih merenja koja je sproveo Wioland (1991: 48), a prema kojima je slog, koji se percipira kao naglašeni slog, duži u 90\% ispitanih slučajeva, dok, pored duženja naglašenog sloga, do neznatnih variranja $\mathrm{F}_{0}$ dolazi u 56\% slučajeva, a do povećanja akustičkog intenziteta samo u $27 \%$ slučajeva.

Wioland (1991: 48) konstatuje i da do istovremenog variranja sva tri parametra u naglašenom slogu, a u primerima na kojima je izvršio merenja dolazi samo u $17 \%$ slučajeva, dok se u $42 \%$ slučajeva realizuje variranje samo dva parametra, a u 38\% samo jednog, kao i da se u najvećem broju kombinacija javlja povećanje trajanja.

U vezi sa ovom osobenošću francuskog akcenta, prema kojoj trajanje naglašenog sloga predstavlja akcenatski marker i igra ključnu ulogu u percipiranju akcenta, Pierre Léon (1998: 107) konstatuje da je naglašeni slog u francuskom jeziku približno dva puta duži od nenaglašenog, a usled duženja vokala u njemu.

Kada je u pitanju mesto akcenta u francuskom jeziku, važno je napomenuti da francuski akcenat koji se realizuje duženjem vokala u naglašenom slogu, pogađa poslednji slog ritmičke grupe.

Ritmička grupa predstavlja minimalnu jedinicu ritmičkog uređenja u francuskom jeziku i uglavnom koincidira sa minimalnom sintaksičkom jedinicom - sintagmom. Samim tim, ona predstavlja vrlo fleksibilnu formu jer se može sastojati od jedne ili više akcentogenih reči koje će sve izgubiti svoj potencijalni akcenat (akcenat koje bi nosile na poslednjem slogu kada bi se samostalno našle u iskazu) u korist poslednje reči, tj. poslednjeg sloga u poslednjoj reči ritmičke grupe.

Ritmički obrazac francuskog jezika sastojao bi se od nekoliko kratkih nenaglašenih slogova iza kojih dolazi dug i naglašen slog.

Fenomen fleksibilnosti ritmičke grupe i njenu sposobnost proširivanja, kao i premeštanje akcenta ka kraju ritmičke grupe pri čemu se ostale reči u ritmičkoj grupi atoniraju mogli bismo ilustrovati primerom un cahier $\rightarrow$ un cahier d'exercices.

U reči un cahier (sveska), akcenat pogađa poslednji slog koji smo podvukli, ali ako se ovoj reči doda dopuna d'exercices, dobija se sintagma 
un cahier d'exercices (vežbanka) u kojoj se akcenat pomera ka kraju sintagme, tj. na poslednji slog reči exercices koji smo podvukli.

Zbog ove karakteristike francukog akcenta, mnogi autori, kao što su Carton (1974: 98), Champagne-Muzar i Bourdages (1998: 28) i Monique Léon (2003: 103) francuski akcenat nazivaju akcentom grupe (accent de groupe), što je termin koji ćemo i mi u ovom radu koristiti.

Kada je reč o maksimalnom broju slogova od kojih se jedna ritmička grupa može sastojati, mišljena su različita, pa tako Landercy i Renard (1977: 101) konstatuju da je maksimalan broj slogova po ritmičkoj grupi osam, Lhote (1995: 138) primećuje da taj broj retko prelazi devet. Na osnovu zaključaka koje su izneli Lauret (2007) i Martin (2009) zaključaka možemo primetiti da su i jedni drugi u pravu.

Naime, Lauret (2007: 44) primećuje da će broj slogova po ritmičkoj grupi biti veći ukoliko je tempo govora brži, i obrnuto, dok Martin (2009: 105-106) precizira da, ukoliko se govori uobičajenim govornim tempom, ritmička grupa najčešće ima maksimalno 7 slogova, a da se, s druge strane, sa ubrzavanjem tempa govora, ritmička grupa može produžiti do 10-11 slogova.

Kada je u pitanju intonacija proste izjavne rečenice $u$ francuskom jeziku, kretanje intonativne krivulje karakteristično za ovaj tip klauze, najjezgrovitije i najtačnije bi se moglo opisati konstatacijom Monique Léon (2003: 108) prema kojoj intonativna krivulja u prostoj izjavnoj rečenici, posle početnog rasta sa nivoa $2^{2}$, vrhunac dostiže otprilike na polovini iskaza (nivo 3) posle čega dolazi do njenog spuštanja i, na kraju, pada do nivoa $1^{3}$, tj. ispod nivoa osnovne frekvencije sa kojeg je iskaz počeo.

\section{Akcenat i ritam u srpskom jeziku i intonacija proste izjavne rečenice}

Srpski, tj. novoštokavski akcenatski sistem obuhvata četiri tipa akcenata: kratkosilazni ("), kratkouzlazni ('), dugosilazni (Ç) i dugouzlazni (').

2 Nivo 2 je referentni nivo $F_{0}$ sa kojeg počinju svi iskazi.

3 Sistem od četiri intonativna nivoa koji podsećaju na linije notnog sistema na koje se smeštaju intonativne krivulje, prvi je, 1945. godine, upotrebio Kenet Pajk (Kenneth Pike). U opisu francuske intonacije, francuski autori, poput Fora (Faure, 1970: 104) i Leona (Léon, 1998: 125), takvom sistemu od četiri nivoa, dodali su i peti za fenomene ekspresivnosti. 
Kada je reč o akustičkim karakteristikama novoštokavskog akcenatskog sistema, to jest, o parametrima koji doprinose percipiranju naglašenog sloga, s jedne, i koji diferenciraju silazne od uzlaznih akcenata, s druge strane, ukazaćemo na Ivićeve stavove zasnovane na analizama rezultata eksperimentalnih merenja.

Prema Iviću (Ивић, Лехисте, 1996: 283), neprihvatljiv je stav da se percipiranje naglašenog u odnosu na nenaglašeni slog, kao i razlikovanje između silaznih i uzlaznih akcenata realizuje isključivo putem razlika u intenzitetu, ili ravnopravnim i združenim dejstvom intenziteta i osnovne frekvencije, jer ,не йосйоји јасна разлика у иниеензииейу ни између акценитованих и иоослеакценайских слоїова, а ни између gва ииийа акиенайа.“ (Ивић, Лехисте, 1996: 70).

Identifikaciji naglašenog sloga u srpskom jeziku doprinose, zapravo, zajedničkim dejstvom, tonska visina tj. osnovna frekvencija $\mathrm{F}_{0}$ koja na naglašenom slogu, a u slučaju uzlaznih akcenata i na akcentovanom $i$, jednim delom, na posleakcenatskom slogu reči dostiže najvišu vrednost, i trajanje vokala u naglašenom slogu, budući da je vokal u akcentovanom slogu znatno duži od vokala u neakcentovanom položaju (Ивић, Лехисте, 1996: 75).

Dakle, može se reći da se, u srpskom jeziku, isticanje određenog sloga realizuje združenim kvalitativnim (variranje osnovne frekvencije $\mathrm{F}_{0}$ ) i kvantitativnim (trajanje sloga) nijansiranjem, dok je snaga ekspiracije (intenzitet) u drugom planu.

Kada je u pitanju mesto srpskog akcenta, on je slobodan, tj. može se naći na svakom slogu osim na poslednjem.

Minimalnu ritmičku jedinicu u srpskom jeziku koja upravlja ritmičkim uređenjem iskaza predstavlja akcenatska jedinica koja je, u srpskoj literaturi, poznata pod nekoliko različitih naziva kao što su akcenatski takt (Милетић, 1952: 67), akcenatska reč (Ивић, Лехисте, 1996: 195) ili akcenatska celina (Дешић, 2003: 79), koji, u principu, upućuju na isto viđenje da minimalna ritmička jedinica sadrži jedan naglašeni slog i da se može sastojati od jedne akcentogene reči ili od grupe reči koja obuhvata akcentogenu reč sa klitikama koje ne mogu biti naglašene.

Tako se, prema Dešiću (Дешић, 2003: 84), iskaz Noću se odvode osuđeni na izdržavanje kazne ili u progonstvo, sastoji od sledećih šest akcenatskih celina: Noću se / odvode / osuđeni / na izdržavanje / kazne / ili u progonstvo. 
U vezi sa intonacijom proste izjavne rečenice u srpskom jeziku, treba reći da se, prema zapažanjima naših značajnijih autora iz predeksperimentalnog perioda, poput Miletića (Милетић, 1937: 220) і Ресе (Пецо, 1971: 2), koja su zasnovana na auditivnim impresijama, intonativni obrazac izjavne rečenice odlikuje tonskim usponom u njenom prvom delu, posle čega na kratko vreme frekvencija ostaje nepromenjena, a zatim postepeno pada ka kraju iskaza.

Kasnija eksperimentalna istraživanja o kretanju osnovne frekvencije $\mathrm{F}_{0}$ koja je sproveo Pavle Ivić potvrdila su navedena zapažanja, a Ivić je došao do zaključka da je ,инйонащиона линија ирростие изјавне реченице силазна.“ (Ивић - Лехисте 1996: 227).

Ovde želimo da primetimo da se srpski i francuski akcenatski i ritmički sistem razlikuju i po akustičkim parametrima koji doprinose identifikaciji naglašenog sloga, kao i po mestu gde se relevantne vrednosti akustičkih parametara javljaju u akcenatskoj celini u srpskom, odnosno u ritmičkoj grupi u francuskom jeziku.

Naime, u francuskoj ritmičkoj grupi koja može da se sastoji i od nekoliko akcentogenih reči, akcenat se realizuje ponajviše duženjem vokala u poslednjem slogu ritmičke grupe, dok na navedenom slogu nema znatnijih variranja $\mathrm{F}_{0} \mathrm{i}$ intenziteta $\mathrm{u}$ odnosu na slogove koji mu prethode.

S druge strane, u srpskom jeziku, akcenat može da se realizuje na svakom slogu osim na poslednjem, a najčašće se realizuje na prvom slogu akcenatske celine koja može da se sastoji od jedne akcentogene reči ili akcentogene reči i klitike/klitika, i to duženjem vokala i variranjem tonske visine, tj. osnovne frekvencije.

\section{Kontrastivna istraživanja na polju prozodije francuskog i srpskog jezika}

U do sada jedinom kontrastivnom istraživanju na polju francuske i srpske prozodije (Šotra, 2006: 105-145), koje je rezultiralo i svojevrsnim intonodidaktičkim konceptom, za naš rad prvenstveno je značajna postavka o međujezičkoj permeabilnosti kojom Šotra (2006: 121-133), zapravo, označava probijanje prozodijskog kôda maternjeg (srpskog) u strani jezik (francuski).

Govoreći o prozodijskoj međujezičkoj propustljivosti, to jest permeabilnosti, Šotra (2006: 121) primećuje da se kod srbofnih studenata, pa čak 
i kod onih koji su stekli artikulacijsku kompetenciju, veoma lako u govoru prepozna prenošenje srpskog akcenatskog i ritmičko-melodijskog kôda koji odudara od francuskog akcenta grupe i uređivanja iskaza u ritmičke grupe.

Šotra (2006: 121) primećuje i da se mogu razlikovati dva tipa permeabilnosti, pa tako, prva permeabilnost pogađa reč i obuhvata preslikavanje samog akcenatskog kôda srpskog jezika koji se, kako konstatuje Šotra (2006: 121-122), odlikuje:

- uzlazno-silaznim politonalnim variranjem unutar akcenatske celine;

- izrazitom tonskom dinamikom unutar sloga;

- većim opsegom tonova u kraćem vremenu i najčešće akcentovanjem prvog ili drugog sloga (a nikada poslednjeg), što je u potpunoj suprotnosti sa francuskim akcentom grupe koji se realizuje duženjem poslednjeg vokala u ritmičkoj grupi.

Na osnovu eksperimentalnog istraživanja u računarskom softveru za analizu govora PRAAT, Šotra (2006: 121) primećuje da srbofoni učenici, kada izgovaraju dvosložne ili višesložne francuske reči, a usled akcenatskog obrasca srpskog jezika koji se zasniva na vokalskoj politonalnosti, automatski prenose takav obrazac i u francuski jezik, pa u otvorenim slogovima dolazi do tonskog variranja.

Kada je u pitanju druga permeabilnost, ona se, prema Šotri (2006: 127), ispoljava prodiranjem ritmičko-melodijskog kôda srpskog jezika u francuski.

Kako primećuje Šotra (2006: 119), dok, u srpskom jeziku ritam rečenice i njenu intonaciju određuju akcenatske celine koje akcenat nose najčešće na prvom, a nikada na poslednjem slogu, ritmom francuske rečenice upravljaju ritmičke grupe koje mogu da se sastoje i od nekoliko akcentogenih reči, a koje će akcenat (koji se realizuje duženjem vokala u poslednjem slogu ritmičke grupe) imati uvek na poslednjem slogu.

Usled takvih ritmičkih razlika, druga permeabilnost u slučaju francuskog jezika u produkciji srbofonih studenata, očituje se potpunim izvrtanjem izvornog francuskog ritma, to jest prebacivanjem akcenta sa dugog poslednjeg sloga poslednje reči ritmičke grupe na svaku reč unutar RG (prema kalku akcentovanja srpske akcenatske celine gde je 1 akcentogena reč $=1$ akcenatska celina) i to na pretpostavljeni akcentovani slog, to jest prvi ili drugi. 


\section{Korpus, ispitanici i obrada korpusa}

Korpus rečenica na kojem smo izvršili istraživanje, sastoji se od četiri francuske proste izjavne rečenice i njihovih prevoda na srpski jezik. Ove rečenice formirali smo vodeći se principom progresivnih stupnjeva, pa se svaki sledeći iskaz proširuje za po jednu sintagmu.

Naš korpus sastoji se od sledećih francuskih prostih izjavnih rečenica (u kojima smo naznačili i podelu na ritmičke grupe) i njihovih prevoda na srpski jezik (sa obeleženom podelom na akcenatske celine):
A. $\quad$ Elle part.
B. $\quad$ Elle part / à Paris.
C. $\quad$ Elle part / à Paris / jeudi.
D. Elle part / à Paris / jeudi soir.
A. Ona / odlazi.
B. Ona / odlazi / u Pariz.
C. Ona / odlazi / u Pariz / u četvrtak.
D. Ona / odlazi / u Pariz / u četvrtak / uveče.

Za ispitanika smo odabrali studenta I godine francuskog jezika sa Filološkog fakulteta u Beogradu ${ }^{4}$, a u eksperimentu je učestvovao i kontrolni ispitanik, to jest, izvorni govornik francuskog jezika čiji snimci predstavljaju referentni prozodijski model sa kojim smo poredili produkciju našeg studenta ${ }^{5}$.

U vezi sa tumačenjem grafikona, značajno je napomenuti da je, u njihovoj donjoj polovini prikazana intonativna krivulja iskaza. Intonativna krivulja iskaza je linija osnovne frekvencije $\mathrm{F}_{0}$ koja, zapravo, predstavlja vibriranje glasnica koje percipiramo kao visinu glasa. Variranje krivulje osnovne frekvencije $\mathrm{F}_{0}$ izraženo je $\mathrm{u}$ hercima $(\mathrm{Hz})$ na vremeskoj osi u se-

$4 \quad$ Snimanje korpusa obavili smo u periodu februar-mart 2009. godine, a u snimanju je učestvovao student I godine Miljan J. iz Beograda i izvorni govornik francuskog jezika Mme Brigitte Mladenović.

5 Usled nedostatka prostora, i zbog obilja materijala, prinuđeni smo da detaljno predstavimo rezultate analiza na izgovoru samo jednog studenta, u ovom slučaju I godine, kod kojeg najviše dolaze do izražaja fenomeni koji bi se mogli nazvati prozodijskim međujezikom. 
kundama ( $s$, a krivulja je prekinuta na mestima gde se javljaju bezvučni suglasnici i pauze.

U gornjoj polovini grafikona, prikazani su oscilogrami koji predstavljaju oscilacije koje je primio mikrofon, a koje odgovaraju intenzitetu glasova. Najveći raspon oscilacija i, samim tim, najveći intenzitet imaju samoglasnici, zvučni suglasnici imaju znatno manji raspon oscilacija, dok najmanji raspon i najmanji intenzitet imaju bezvučni suglasnici.

Najvažniji preduslov za početak merenja u PRAAT računarskom softveru, predstavlja pravilno određivanje opsega osnovne frekvencije $\mathrm{F}_{0}$ u kojem se kreće glas govornika. Ovaj opseg se, u principu, za govornike muškog pola kreće od 75 do $200 \mathrm{~Hz}$, a za informatore ženskog pola, prema tvorcima PRAAT softvera, od 100 do $500 \mathrm{~Hz}^{6}$.

Posle utvrđivanja opsega u kojem se kreće informatorov glas, prelazi se na određivanje trajanja u sekundama najdužeg iskaza (označenog velikim slovom D u primerima sa četiri iskaza, odnosno $\mathrm{C}$ u slučaju primera sastavljenih od tri iskaza), a tako dobijenu vremesku osu koristimo kao „referentni okvir“ na koji je, potom, smeštena krivulja svakog od iskaza od kojih se sastoji dati primer.

\section{Analiza rezultata merenja na korpusu francuskih i srpskih prostih izjavnih rečenica}

Po okončanju čisto tehničke faze rada, pristupili smo analizi rezultata merenja, tokom koje smo se vodili komparativno-kontrastivnom metodom rada.

Tako ćemo, najpre, rezultate merenja na francuskim iskazima u interpretaciji izvornog govornika francuskog jezika koji predstavlja referentni prozodijski model, porediti sa krivuljama dobijenim analizom francuskih iskaza u izgovoru srbofonog studenta, kako bismo utvrdili tačke približavanja i razmimoilaženja između njih.

Potom ćemo intonativne krivulje dobijene analizom snimaka francuskih iskaza u izgovoru našeg studenta, porediti, s jedne strane, sa referentnim francuskim prozodijskim modelom, a s druge, sa krivuljama srpskih rečenica u njegovoj interpretaciji kako bismo locirali mesta na kojima dolazi do ,probijanja“" srpskog prozodijskog kôda u francuski.

6 http://www.fon.hum.uva.nl/praat/manual/Intro_4_2_Configuring_the_pitch_ contour.html 
Analizu našeg eksperimentalnog korpusa započinjemo interpretacijom grafikona dobijenih merenjima na primerima izjavnih rečenica, a od primera izjavnih iskaza koja smo u istraživanju obradili, a koje zbog nedostatka prostora ovde ne možemo u potpunosti predstaviti i opisati, opredelili smo se da detaljnije obradimo onaj primer koji jasno ukazuje na prozodijske karakteristike ove vrste kako francuskih, tako i srpskih iskaza.

Na slici 1, vidimo transkripciju melodijske krivulje iskaza Elle part koji se, u interpretaciji izvorne govornice sastoji od jedne ritmičke grupe (RG) od 2 sloga.

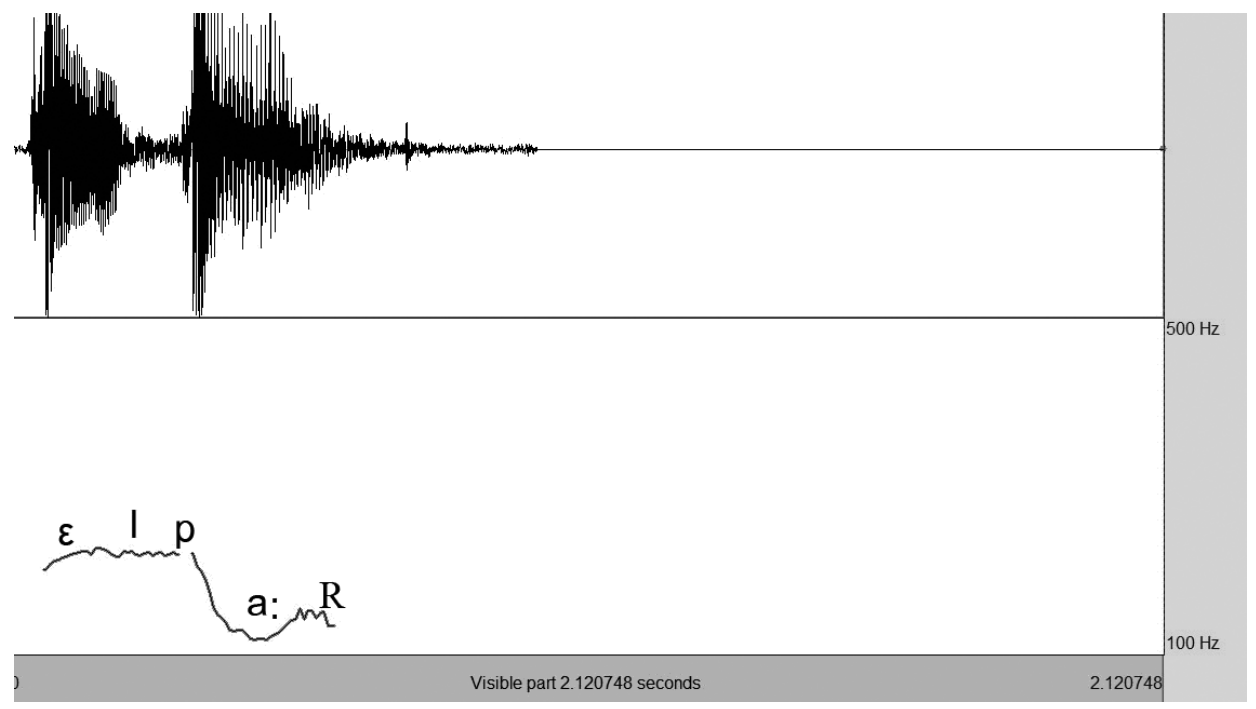

Slika 1. Iskaz Elle part u interpretaciji izvornog govornika (B.M.), 1 RG.

$\mathrm{Na}$ ovom grafikonu, konstatujemo zaravnjenu krivulju na Elle, silaznu intonemu na part sa tipičnim zaravnjenim delom na poslednjem, to jest, naglašenom slogu RG part, koji ukazuje na mesto akcenta (poslednji slog RG) i akustičku prirodu francuskog akcenta grupe (ne realizuje se povećanjem $\mathrm{F}_{0} \mathrm{u}$ odnosu na prethodni slog, već duženjem vokala u naglašenom slogu, koji je otprilike dvostruko duži od nenaglašenih).

Na slici 2 prikazana je krivulja iskaza Elle part / à Paris koji se sastoji od dve RG. 

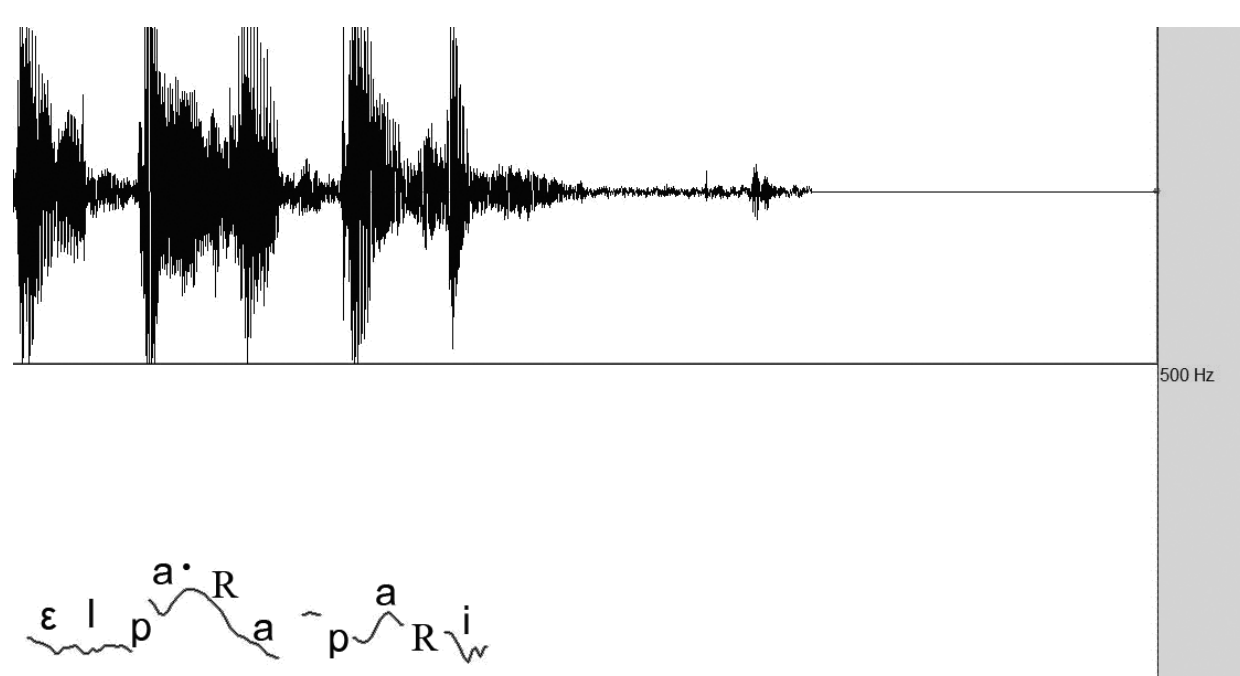

Visible part 2.121769 seconds

2.121769

Slika 2. Iskaz Elle part / à Paris u interpretaciji izvornog govornika (B.M.), $2 R G$.

Primećujemo zaravnjenu krivulju na prvom slogu elle, zatim uzlazno silaznu krivulju na part na koju se, bez pauze, nastavlja druga RG à Paris, usled konsonatskog ulančavanja ${ }^{7}$ između part à Paris. Krivulja se okončava silaznom intonemom na poslednjem slogu druge RG à Paris, gde se i nalazi akcenat, to jest najduži vokal u ovoj RG.

Primećujemo i izostanak vibriranja glasnica tokom artikulacije glasa [R] u međuvokalskom položaju kod Paris.

Opšta slika kretanja intonativne krivulje odgovara Delatrovim (Delattre in Léon, Martin, 1970: 53) teorijskim postavkama da krivulja kod deklarativnog iskaza kreće sa nivoa 2 da bi, otprilike na sredini iskaza dostigla najvišu vrednost $\mathrm{F}_{0}$, odakle se postepeno spušta ka kraju iskaza.

Iskaz se dalje proširuje ritmičkom grupom jeudi: Elle part / à Paris / jeudi (slika 3), pa se sada sastoji od tri RG Elle part (2 sloga) /à Paris (3 sloga) / jeudi (2 sloga). Iskaz počinje na nivou 2, ponovo primećujemo zaravnjenu krivulju na Elle, uzlazno silaznu neprekinutu krivulju na part

7 Konsonantsko ulančavanje (l'enchaînement consonantique) je fenomen koji može da se javi unutar jedne iste, ali i između dve susedne ritmičke grupe. Naime, kada se jedna reč završava konsonantom koji se izgovara, a naredna počinje vokalom, postoji tendencija da se te dve reči izgovore „sliveno“, bez pauze. 
$\grave{a}$, usled konsonantskog ulančavanja, ponovo podizanje frekvencije prema sredini iskaza. $U$ oči pada izuzetno izražena povezanost između tri RG.

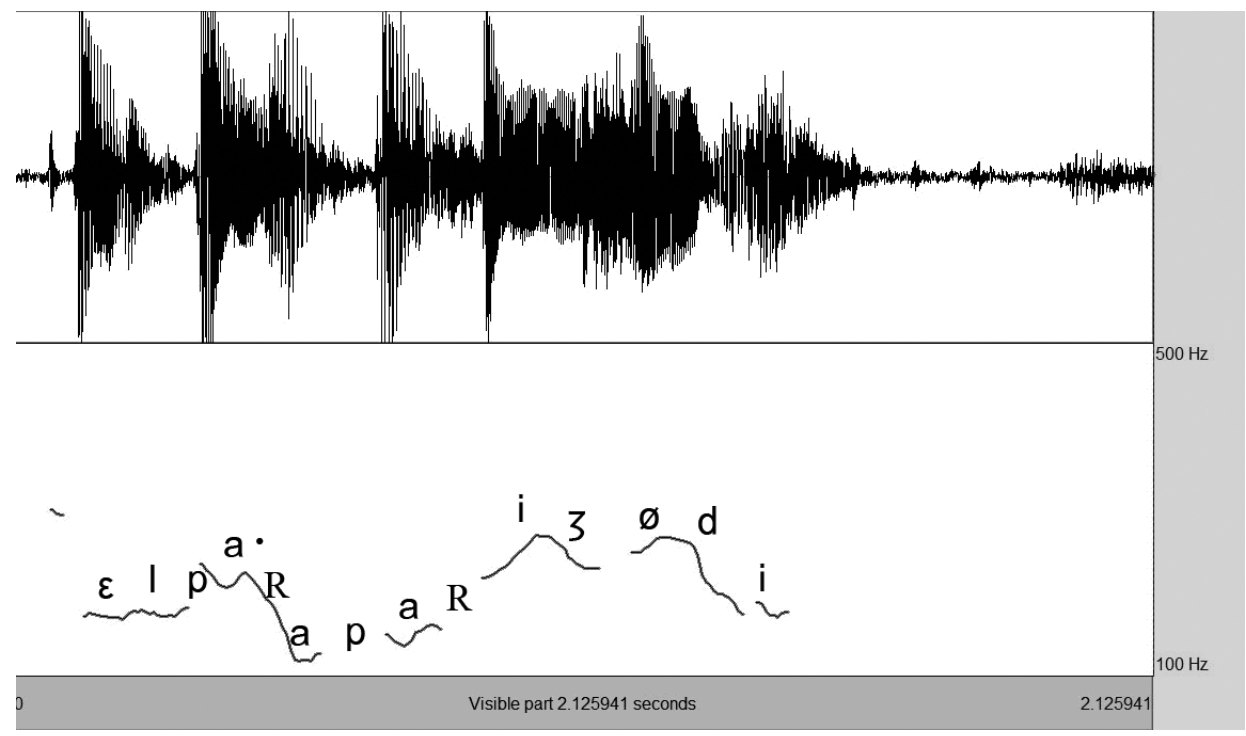

Slika 3. Iskaz Elle part / à Paris / jeudi u interpretaciji izvornog govornika (B.M.), 3 RG.

Prema kraju druge RG, primećujemo, prema Delatrovoj terminologiji (Delattre in Léon, Martin, 1970: 51), intonemu molskog nastavljanja 2-3 kojom su povezane druga i treća $\mathrm{RG}$, a koja se realizuje na poslednjem vokalu (Paris $)$ u drugoj RG, na kojem je krivulja zaobljenog, gotovo zaravnjenog vrha usled akcentovanja, to jest duženja vokala u njoj.

Treća RG (jeudi) sastoji se od 2 sloga a nadovezuje se na drugu, kao što smo rekli, intonemom molskog nastavljanja 2-3.

Krivulja se posle postepenog spuštanja sa jeu- $267 \mathrm{~Hz}$ i -di $266 \mathrm{~Hz}$, okončava na otprilike istoj frekvenciji od $171 \mathrm{~Hz}$ na kojoj je i počela.

Na kraju krivulje, to jest, na kraju treće RG jeudi, primećujemo zaravnjenu krivuju na poslednjem slogu -di, koja ukazuje na realizovanje francuskog akcenta grupe duženjem vokala u poslednjem slogu grupe.

Poslednjim proširenjem, dobijamo iskaz prikazan na slici 4: Elle part à Paris jeudi soir koji se sastoji takođe od $3 \mathrm{RG}$ - Elle part (2 sloga) / à Paris (3 sloga) / jeudi soir (3 sloga). 

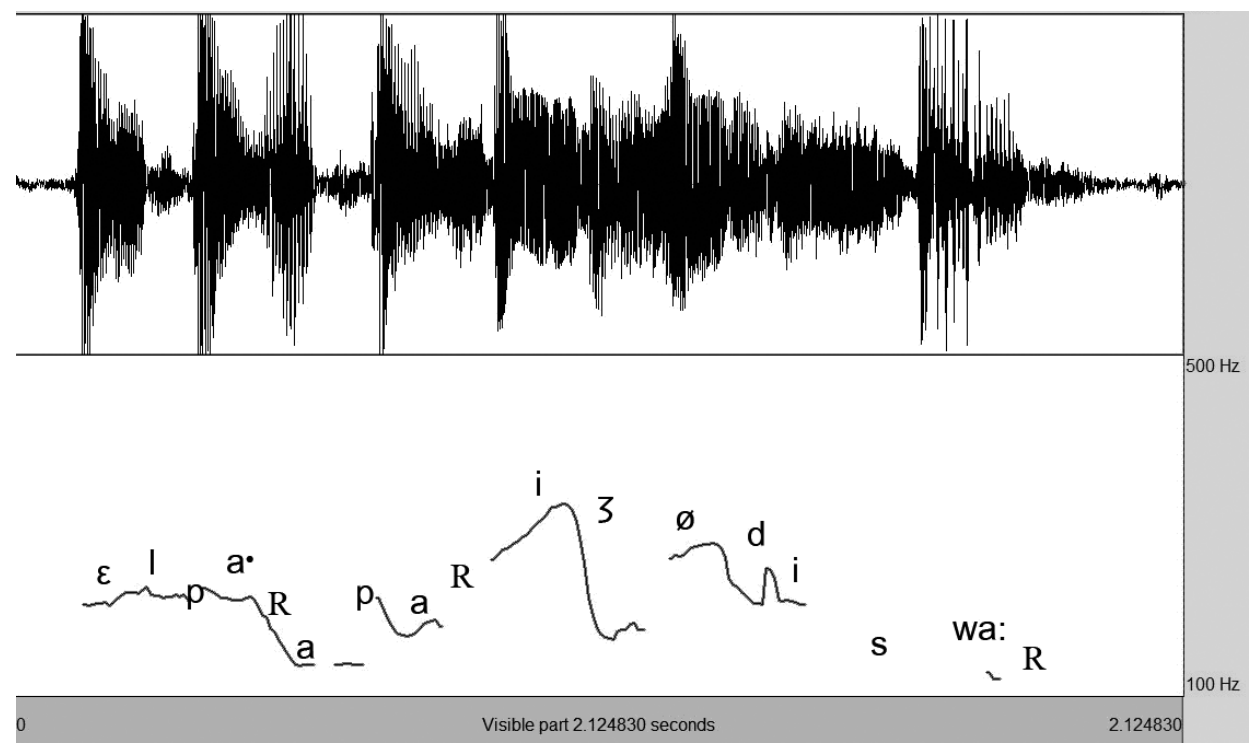

Slika 4. Iskaz Elle part / à Paris / jeudi soir u interpretaciji izvornog govornika (B.M.), $3 R G$.

Kao i u prethodnim primerima, krivulja iskaza počinje sa nivoa 2, zaravnjeno se proteže preko prva dva sloga prve $\mathrm{RG}$, zatim pada da bi potom dostigla na kraju druge RG, a prema sredini iskaza, najviši nivo (324 $\mathrm{Hz}$ ) gde zaravnjeni deo krivulje posle intoneme molskog nastavljanja 2-3 ukazuje na mesto akcenta u drugoj RG na Paris koji se realizuje duženjem vokala [i]. Ovaj vokal traje približno $0,15 \mathrm{sec}$, dok svi ostali ispred njega imaju trajanje od približno $0,07 \mathrm{sec}$.

Prema kraju druge RG, primećujemo intonemu molskog nastavljanja kojom su povezane druga i treća RG, a koja se realizuje na poslednjem vokalu (Paris) u drugoj RG, na kojem je krivulja zaobljenog, gotovo zaravnjenog vrha usled akcentovanja, to jest, duženja vokala u njoj.

Treća RG (jeudi soir) sastoji se od 3 sloga a nadovezuje se na drugu, kao što smo rekli intonemom molskog nastavljanja 2-3. U odnosu na prethodni iskaz, treća RG proširuje se udesno za jedan slog, pa se samim tim i akcenat premešta na poluvokal [wa].

Posle merenja na iskazima u interpretaciji izvornih govornika, prikazujemo i podatke koje smo dobili snimanjem srbofonog studenta I godine studija kod kojeg se najbolje mogu videti međujezička prozodijska preslikavanja. 

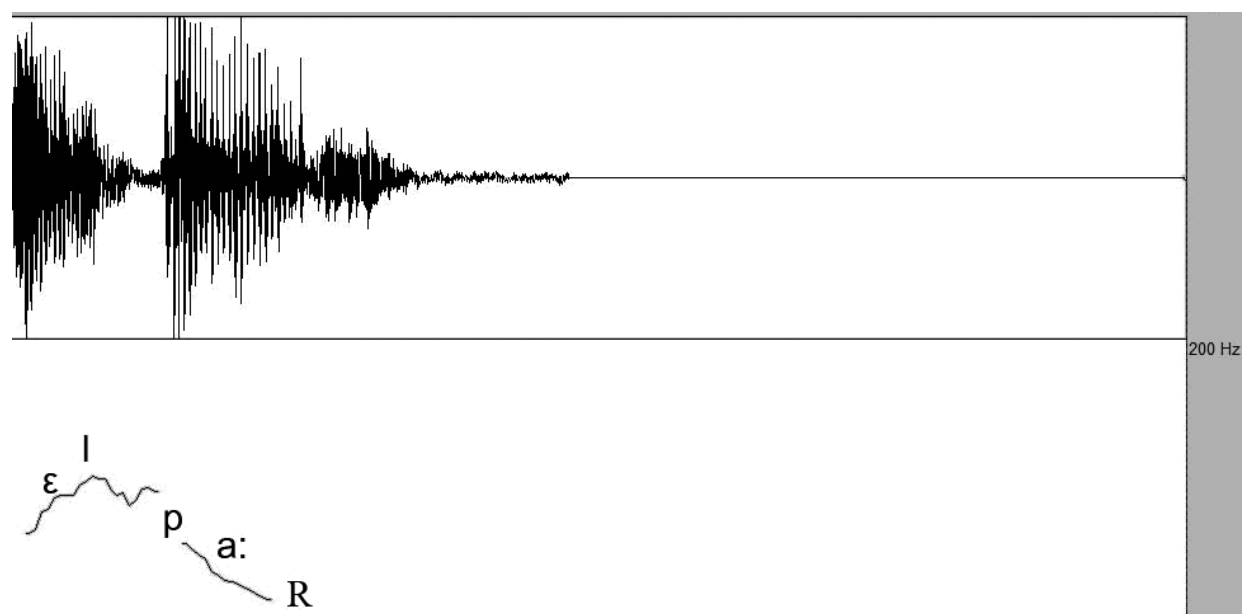

Slika 5. Iskaz Elle part $u$ interpretaciji studenta I godine (Miljana J.).

Iskaz Elle part u intrepretaciji studenta I godine (Miljana J.) prikazan je na slici 5 na kojoj odmah konstatujemo odudaranje od grafikona iskaza u interpretaciji izvornih govornika.

Naime, na prvom slogu iskaza [عl], na kojem je, u slučaju francuskih govornika, krivulja zaravnjena budući da je reč o prvom i samim tim nenaglašenom slogu $R G$, u slučaju našeg studenta primećujemo uzlazno kretanje melodije (na vokalu $[\varepsilon]$ konstatujemo kretanje $\mathrm{F}_{0}$ od 124,9 Hz do 135 $\mathrm{Hz}$, dok se vrhunac $\mathrm{F}_{0}$ na slogu [El] nalazi na $147,4 \mathrm{~Hz}$ ), a zatim postepeni pad sve do kraja iskaza.

U slučaju francuskog iskaza, važno je napomenuti da nenaglašena lična zamenica, u ovom slučaju zamenica Elle, nikada ne može da nosi akcenat, to jest, da oformi RG: zamenica obrazuje RG zajedno sa ličnim glagolskim oblikom uz koji stoji.

Samim tim, budući da se nalazi u prvom, nenaglešnom slogu RG, na njoj ne može doći do melodijskog variranja niti do duženja vokala.

Grafikon svedoči o organizaciji ovog francuskog iskaza shodno srpskoj ritmičkoj shemi prema kojoj se reči grupišu u akcenatske celine (AC), usled čega ovde dolazi do sledeće ritmičke organizacije Elle / part, nemoguće u francuskom jeziku. 
O ovome još rečitije govore i rezultati koje smo dobili merenjem trajanja slogova u ovom i svim sledećim francuskim iskazima.

Usled organizacije reči u AC, slogovi su približno jednakih dužina, pa tako [عl] traje 0,21 sekundu, a slog [pa:R], umesto da traje dvostruko duže što je bio slučaj kod izvornog govornika, traje svega 0,28 sekundi i to uglavnom zbog realizacije duženja vokala [a] iza kojeg dolazi konsonant [R].

Ako pogledamo krivulju dobijenu obradom snimka prevoda ovog iskaza na srpski, koji se sastoji od dve AC Ona / odlazi, u interpretaciji istog govornika, možemo da konstatujemo slično ponašanje melodijske krivulje na prvom vokalu prve AC Ona.
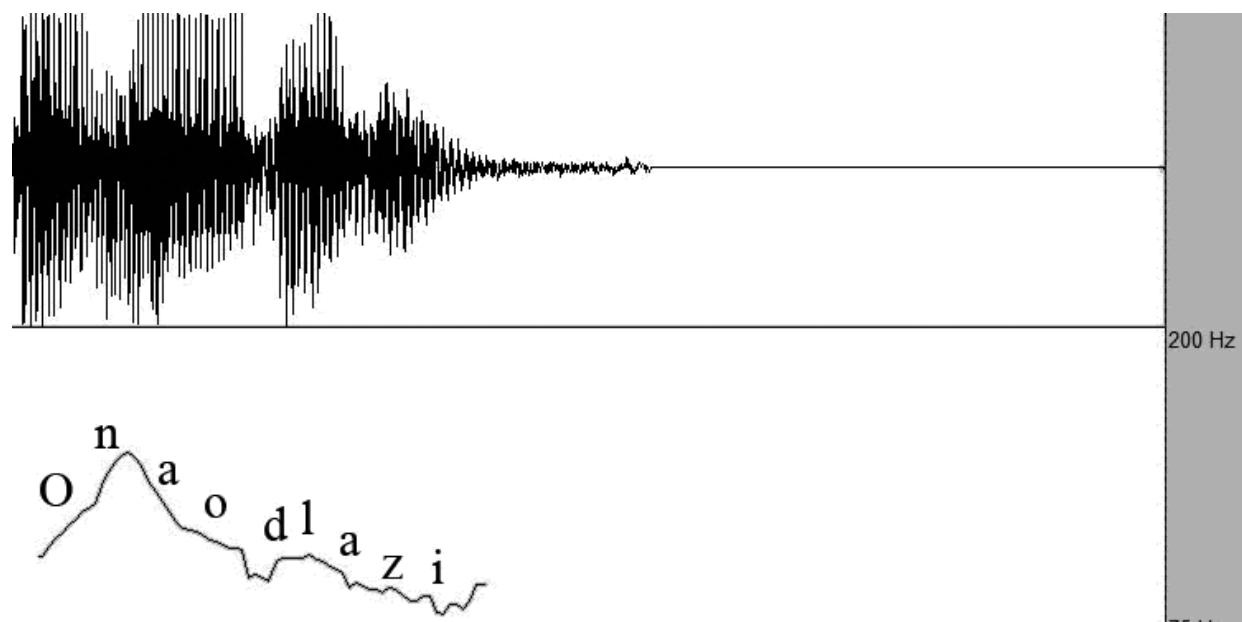

Visible part 1.741587 seconds

Slika 6. Iskaz Ona/odlazi (2 AC) u interpretaciji studenta I godine (M.J.).

Kao i na prethodnom grafikonu koji predstavlja francuski iskaz Elle part, melodijska krivulja, i ovde, raste na početku iskaza, što je u srpskom primeru, za razliku od francuskog, sasvim prirodno jer lična zamenica Ona predstavlja prvu AC na kojoj se nalazi kratkouzlazni akcenat usled kojeg i dolazi do uzlaznog kretanja melodije. Na samoglasniku $O$, konstatujemo variranje $F_{0}$ od 109,2 do 131,4 Hz, pa je ovo objašnjenje zašto se slično variranje realizovalo na slogu $[\varepsilon 1] \mathrm{u}$ prvom francuskom iskazu u interpretaciji ovog srbofonog subjekta i egzaktna potvrda teze o preslikavanju prirode srpskog akcenta na nivou reči u francuski jezik (Šotra, 2006: 121-133). 
Melodijska linija se, i u ovoj srpskoj rečenici i u ostalim rečenicama iz ovog primera,spušta ka kraju iskaza, što je u potpunoj saglasnosti sa Ivićevim zaključkom da je „инйонациона линија иростие изјавне реченице силазна.“ (Ивић, Лехисте, 1996: 207).

Proširivanjem iskaza udesno dobijamo iskaze Elle part à Paris, odnosno Ona / odlazi / u Pariz.

$\mathrm{Na}$ ovako proširenom iskazu, konstatujemo značajno prozodijsko podudaranje između francuskog i srpskog iskaza, odnosno preslikavanje akcenta i ritma maternjeg jezika u strani jezik.

Tako se srpskom jeziku svojstveno kretanje gore-dole usled prelaska sa naglašenog na nenaglešeni slog i višetonalna variranja u kratkom vremenu koja se na grafikonu realizuju u vidu oštrih vrhova krivulje, gotovo u celosti prepoznaju i u francuskoj rečenici u interpretaciji ovog govornika.

U francuskom iskazu ponovo se prepoznaje srpsko ritmičko uređivanje iskaza u AC, pa je govornik iskaz izgovorio kao da se sastoji od 3 celine Elle / part / à Paris, što je suprotno pravilima francuske prozodije.

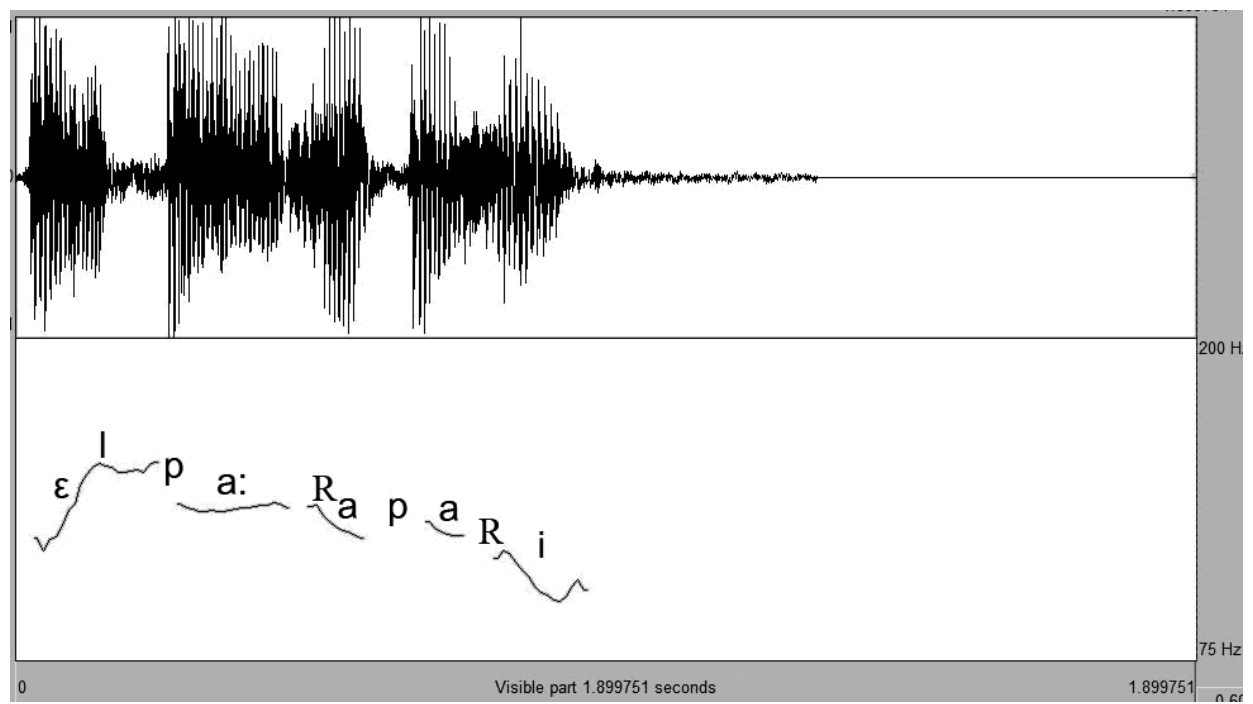

Slika 7. Iskaz Elle part à Paris u interpretaciji studenta I godine (M.J.).

U francuskom iskazu u interpretaciji našeg studenta, poslednji slog koji bi, prema pravilima francuske akcentuacije i ritmičkog uređenja, trebalo da bude dvostruko duži od svih prethodnih (nenaglašenih), traje svega 
0,21 sekundu ( [عl] traje 0,20, [pa:R] 0,18, [a] 0,08, [pa-] 0,16 i [-Ri] 0,21 sekundu).

U srpskom iskazu sa slike 8, konstatujemo uticaj rečenične prozodije na prozodiju reči, budući da bi toponim Pàriz trebalo da ima kratkouzlazni akcenat.

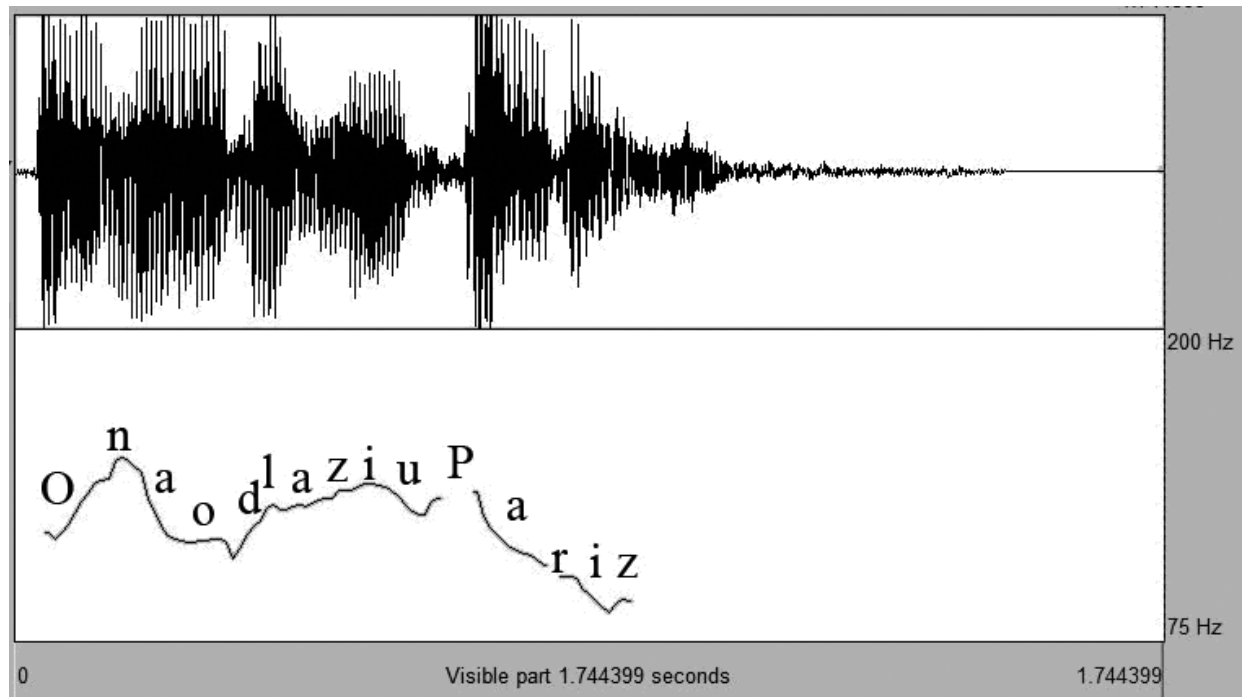

Slika 8. Iskaz Ona/odlazi/u Pariz (3 AC) u interpretaciji studenta I godine (M.J.).

Kada su u pitanju reči u finalnoj poziciji u iskazu, kako primećuje Ivić (Ivić, Lehiste, 1996: 210), „силазна основна фреквенција и лариніализација јављају се и коg силазних и коg узлазних акценайа,

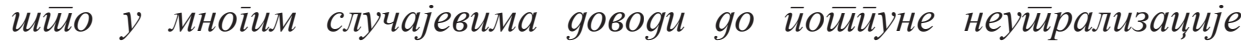
оиозиције између оова gва акиенайска тиийа."

Pošto je reč Pàriz u finalnom položaju koji se karakteriše silaznom $\mathrm{F}_{0}$, u njoj će, usled uticaja globalnog kretanja $\mathrm{F}_{0}$, doći i do neutralizacije uzlaznog akcenta koji će biti zamenjen silaznim (na akcentovanom slogu konstatovali smo kretanje $\mathrm{F}_{0}$ od 134,9 do $106 \mathrm{~Hz}$ ), a konstatovali smo i laringalizaciju na krajnjem slogu reči.

Daljim proširivanjem iskaza, dobili smo iskaz sa podelom na sledeće celine Elle / part / à Paris / jeudi, koji govornik „,secka“ shodno urođenom srpskom obrascu deljenja iskaza na AC (,,sukcesivni ritam“ $)^{8}$. 


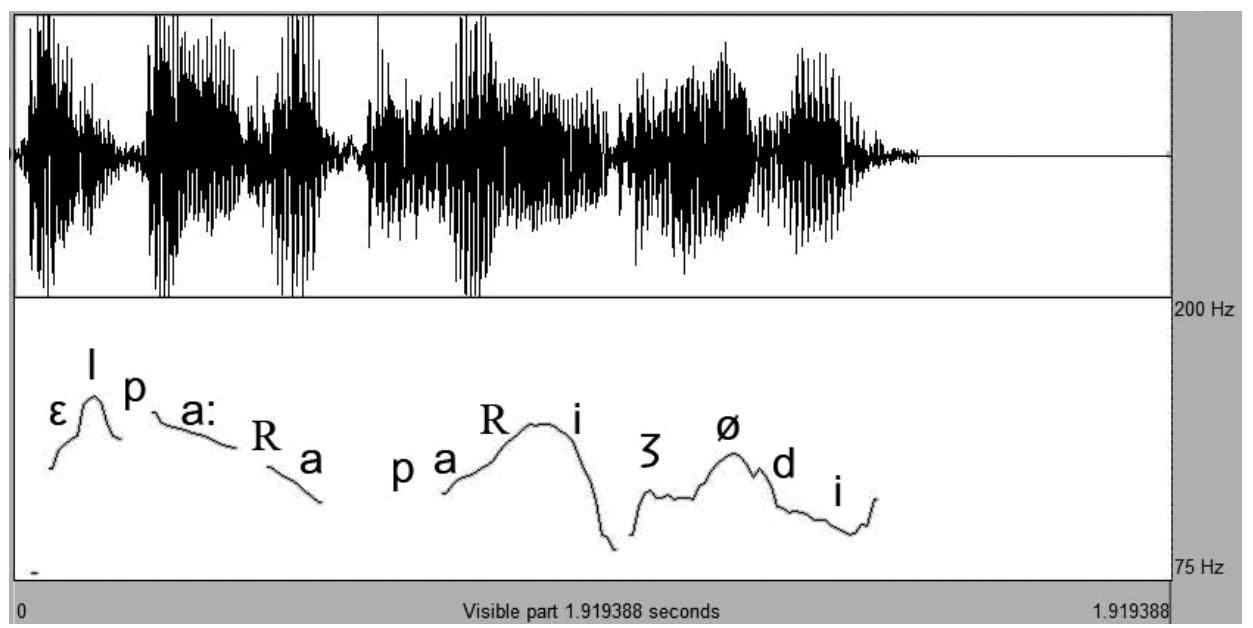

Slika 9. Iskaz Elle part à Paris jeudi u interpretaciji studenta I godine (M.J.).

U odnosu na grafikone sa ovim iskazom u interpretaciji izvornih govornika (slika 3), konstatujemo izrazitu nepovezanost kako između članova onoga što bi trebalo da budu RG, tako i između dve RG (treći i četvrti jasno odvojeni deo krivulje) koje bi trebalo da budu realizovane.

Naime, umesto blagog i kontinuiranog uzlaznog prelaza s jedne na drugu RG pomoću intoneme molskog nastavljanja 2-3 u slučaju izvornih govornika, ovde konstatujemo prekid između dve grupe i izraziti pad na slogu [-Ri] (od polovine ka kraju trećeg dela krivulje) koji ukazuje na nesvesno preslikavanje srpskog kretanja gore-dole, to jest, na preslikavanje prelaska sa naglašenog prvog sloga ličnog imena Pariz na njegov drugi i atonirani slog.

Preslušavanjem snimka, konstatovali smo da govornik zaista akcentuje prvi slog reči Paris $\left(\mathrm{F}_{0}\right.$ se kreće od 110 do 122,2 Hz), i prvi slog reči jeudi $\left(\mathrm{F}_{0}\right.$ se kreće od 95 do 130,9 Hz), po urođenom refleksu iz maternjeg jezika (u kojem svi slogovi osim poslednjeg mogu da budu naglašeni, a najčešće je to prvi slog), što se očituje u vidu dva vrha krivulje, od polovine ka kraju iskaza.

Pritom, primećujemo i da govornik previše duži vokal [a] u reči [pa:R], kao da je na kraju RG, i konstatujemo preslikavanje srpskog „sukcesivnog ritma“ $u$ francusku rečenicu.

između naglasaka „,nezavisni (jedan nastaje završetkom drugog)“ (Jovičić, 199: 414), a percipira se kao pokret ,gore-dole“, usled stalnog smenjivanja naglašenih i nenaglašenih slogova. 
PROZODIJSKI MEĐUJEZIK: ISTRAŽIVANJE NA KORPUSU FRANCUSKIH ...
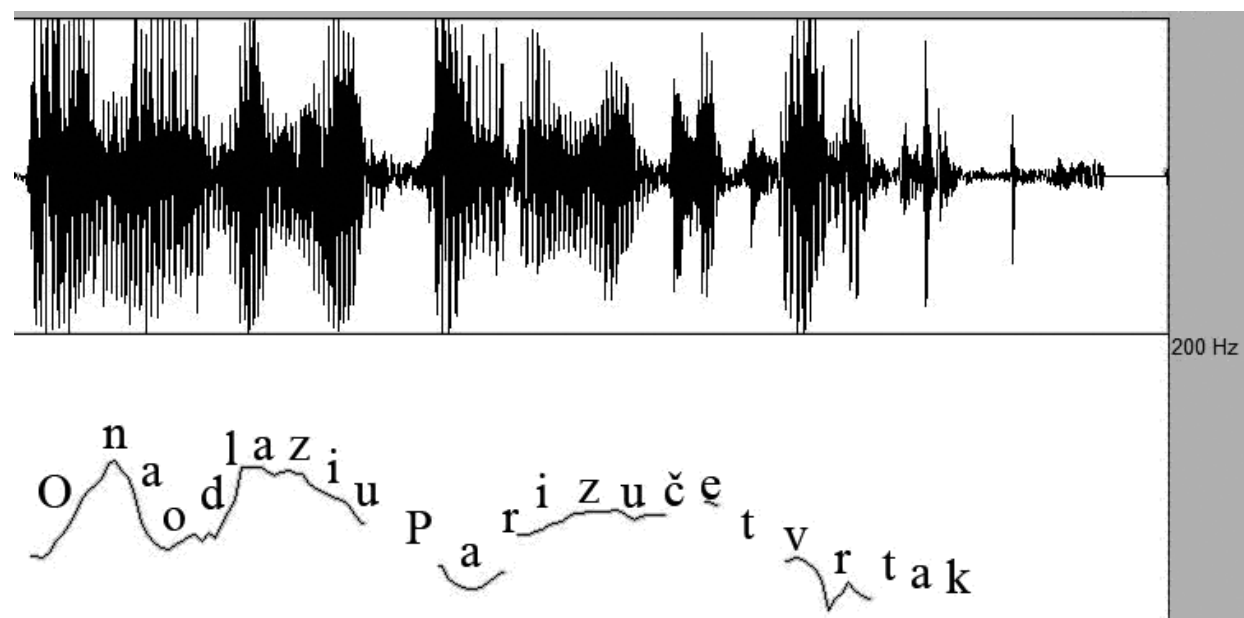

Visible part 1.741202 seconds

Slika 10. Iskaz Ona/odlazi/u Pariz/u četvrtak

(4 AC) u interpretaciji studenta I godine (M.J.).

Dodavanjem imenice soir, dobili smo poslednji iskaz koji se u interpretaciji izvornih govornika sastoji od tri RG: Elle part / à Paris / jeudi soir.

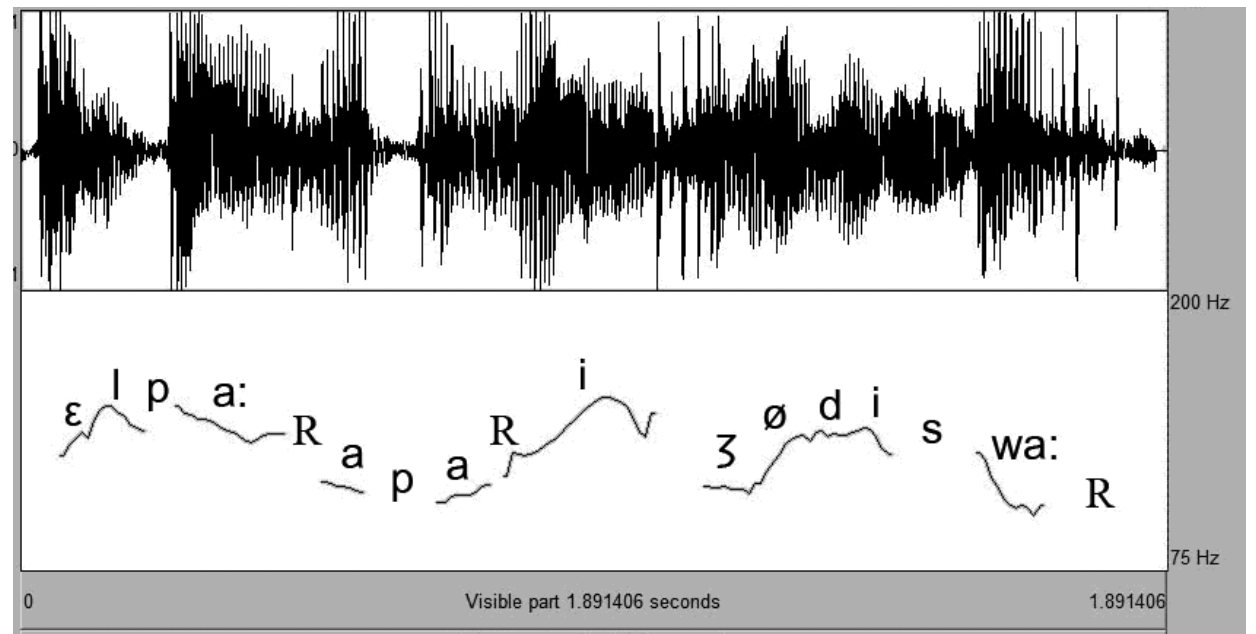

Slika 11. Iskaz Elle part à Paris jeudi soir u interpretaciji studenta I godine (M.J.). 
I na slici 11, uočavamo podelu iskaza shodno srpskom ritmičkom obrascu u AC Elle / part / à Paris / jeudi soir, i usled toga izrazitu nepovezanost kako između segmenata onoga što bi trebalo da budu RG, tako i između tri pretpostavljene RG, kao i kontinuirano uzlazno-silazno kretanje koje odgovara smenjivanju naglašenih i nenaglašenih slogova.

Povezanost koja bi između prve i druge RG trebalo da bude izražena usled pojave konsonatskog ulančavanja Elle part à Paris, potpuno je odsutna $\mathrm{i}$ iz prethodnih i iz ovog francuskog iskaza u interpretaciji našeg studenta. Na ovom grafikonu, uviđamo takođe i svojevrsnu mešavinu grupisanja reči prema dva modela: u srpske akcenatske celine i francuske ritmičke grupe.

Naime, govornik iskaz deli na sledeći način Elle / part/à Paris/jeudi soir, što je sasvim jasan kalk grupisanja reči u AC, osim u slučaju poslednje celine u koju su reči grupisane po principu formiranja francuskih RG.

Samim tim, u ovom francuskom iskazu, jasno se raspoznaje i refleksno srpsko akcentovanje prvog sloga akcentogenih reči, što je očigledno i na slikama 11 i 12 .

Kao i na svim prethodnim grafikonima, i ovde možemo videti potvrdu teze o prozodijskoj permeabilnosti, pa na slici 11 konstatujemo gotovo identične zgusnute uzlazno-silazne krivulje i mesta akcenta prenetog iz srpskog jezika. Ova pojava naročito dolazi do izražaja na početku iskaza kada je akcenat na ličnoj zamenici Ona, odnosno Elle, i na sredini iskaza kod reči Paris, odnosno Pariz.

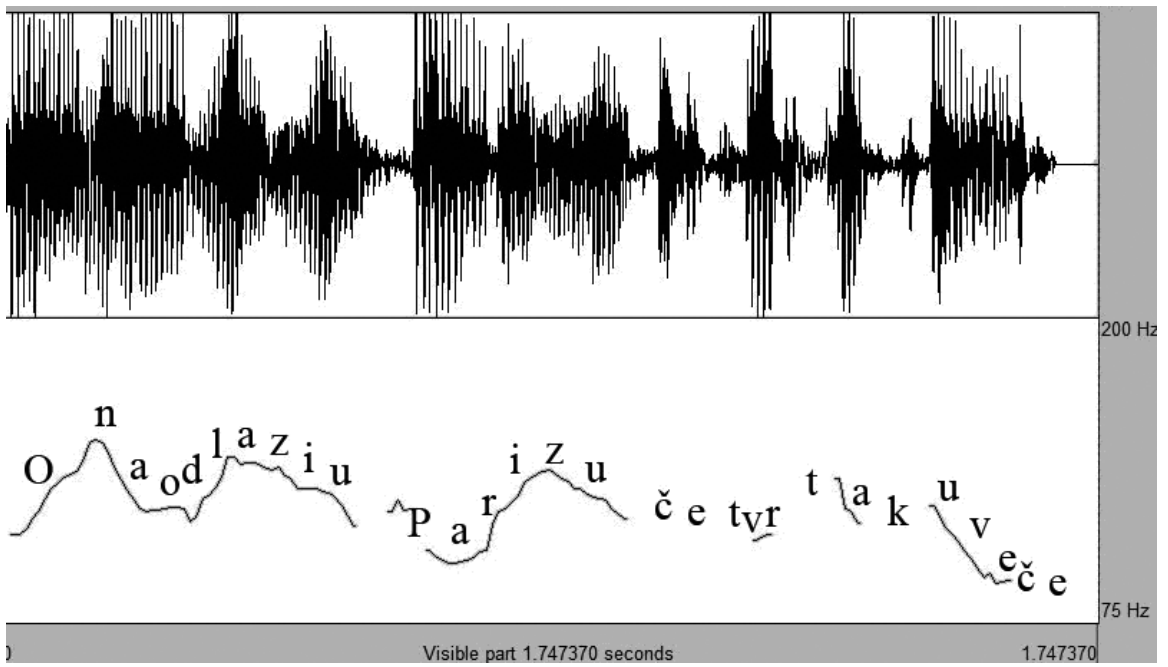

Slika 12. Iskaz Ona/odlazi/u Pariz/u četvrtak/uveče (5 AC) u interpretaciji studenta I godine (M.J.). 


\section{Zaključak}

$\mathrm{Na}$ osnovu svega navedenog, a kada je reč o francuskim prostim izjavnim rečenicama u izgovoru izvornog govornika, pažnju bismo mogli skrenuti na sledeće činjenice:

- kao što polazna hipoteza i govori, intonativna krivulja polazi sa nivoa 2, vrhunac dostiže otprilike na sredini iskaza $\mathrm{i}$ zatim postepeno pada do kraja iskaza gde se spušta ispod nivoa sa kojeg je pošla, a mogli bismo dodati da se $u$ odnosu na krivulje i u francuskim i u srpskim iskazima $u$ interpretaciji srbofonih studenata, odlikuje izuzetno zaravnjenim kretanjem, bez naglih varijacija osnovne frekvencije;

- ritmička organizacija francuskog iskaza podređena je smenjivanju ritmičkih grupa koje na svom kraju nose akcenat, a između kojih nema naglih prekida i koje su povezane blagim prelazima;

- rezultati merenja slogova potvrđuju i vizuelni utisak i opšte prihvaćene stavove francuskih autora da je naglašeni (poslednji) slog u ritmičkim grupama približno dvostruko duži od nenaglašenih slogova koji mu prethode, a usled duženja vokala u njemu.

Kada je u pitanju srbofoni student, želimo da podvučemo da smo u njegovoj interpretaciji francuskih iskaza, jasno prepoznali, i dodatnim merenjima trajanja slogova, potkrepili Šotrine (2006: 121-133) zaključke:

- o probijanju melodijskih karakteristika srpskog akcenatskog sistema (prva permeabilnost), uglavnom, na prvim slogovima reči u francuskim iskazima što je potpuno strano francuskom akcenatskom sistemu, a što je najčešća situacija u srpskom. Ovo probijanje nedvosmisleno smo konstatovali, najpre, opservacijom i komparacijom oblika i vrhova krivulje na određenim srpskim rečima i njihovim francuskim ekvivalentima, a zatim i preciznim merenjima trajanja slogova na kojima smo pretpostavili da je došlo do akcenatskog probijanja;

- o prenošenju u francuski iskaz srpske ritmičke organizacije (druga permeabilnost) koja je podređena smenjivanju akcenatskih celina i stalnom smenjivanju naglašenih i nenaglašenih slogova što rezultira konstantnim uzlazno-silaznim ritmičkim pokretom. I ovu konstataciju takođe smo potkrepili merenjem trajanja slogova koji bi, shodno pravilima francuske ritmičke organizacije, trebalo da budu naglašeni i najduži, tj. poslednjih slogova u celinama koje $\mathrm{u}$ francuskim iskazima $\mathrm{u}$ interpretaciji izvornog govornika čine ritmičke grupe. Pokazalo se da ovi slogovi u francuskim 
iskazima u interpretaciji srbofonih studenata traju približno koliko i svi ostali slogovi.

Samim tim, ovo potvrđuje da srbofoni govornik potpuno zanemaruje organizaciju francuskog iskaza u ritmičke grupe koje odgovaraju smisaonim celinama, a koje na svom poslednjem slogu nose akcenat grupe koji se očituje zaobljenim, gotovo zaravnjenim vrhovima krivulje koji ukazuju na duže trajanje naglašenog sloga.

Takođe smo konstatovali i da se francuski iskazi u izgovoru srbofonog studenta, uglavnom, odlikuju nepovezanošću između celina koje bi trebalo da oforme francuske ritmičke grupe, zatim, da na nekim mestima, protivno svim pravilima, studenti prave jasnu pauzu između ritmičkih grupa, kao i da, najčešće, zanemaruju fenomene vokalskog i konsonantskog ulančavanja koji u slučaju izvornog govornika još više pojačavaju koheziju između ritmičkih grupa koje čine iskaz.

Kada su u pitanju karakteristike intonacije prostih izjavnih rečenica $\mathrm{u}$ francuskom i srpskom jeziku, mogli bismo da zaključimo da je jedina sličnost između srpskih i francuskih prostih izjavnih rečenica koje smo obradili u korpusu silazno kretanje $\mathrm{F}_{0}$ ka kraju iskaza.

$\mathrm{S}$ druge strane, krivulja osnovne frekvencije u francuskim iskazima u izgovoru izvornog govornika odlikuje se izuzetno zaravnjenim i monotonim kretanjem bez izraženijih melodijskih varijacija, dok se srpski iskazi karakterišu značajnim tonskim varijacijama koje se prepoznaju kao stalno $\mathrm{i}$ energično uzlazno-silazno kretanje krivulje $\mathrm{F}_{0}$.

\section{LITERATURA}

Carton, F. (1974). Introduction à la phonétique du français. Paris, Bruxelles, Montréal: Bordas.

Champagne-Muzar, C., Bourdages, J. (1998). Le point sur la phonétique. Paris: CLE international.

Faure, G. (1970). Contribution à l'étude du statut phonologique des strutures prosodématiques. Studia Phonetica 3, 94-108.

Jovičić, S. (1999). Govorna komunikacija, fiziologija, psihoakustika i percepcija. Beograd: Nauka.

Landercy, A., Renard, R. (1977). Éléments de phonétique. Bruxelles: Didier. 
Lauret, B. (2007). Enseigner la prononciation du français: questions et outils. Paris: Hachette.

Léon, M. (2003). Exercices systématiques de prononciation française. Paris: Hachette.

Léon, P., Martin, P. (1970). Prolégomènes à l'étude des structures intonatives. Paris: Didier.

Léon, P. (1998). Phonétisme et prononciation du français. Paris: Nathan Université.

Lhote, É. (1995). Enseigner l'oral en interaction. Paris: Hachette.

Martin, P. (2009). Intonation du français. Paris: Armand Coli.

Šotra, T. (2006). Kako progovoriti na stranom jeziku. Beograd: Zavod za udžbenike i nastavna sredstva.

Wioland, F. (1991). Prononcer les mots du français. Paris: Hachette.

$$
* * *
$$

Дешић, М. (2003). О акценатском прозном ритму у српском књижевном језку (на примјерима из Андрићеве Проклеиее авлије). Зборник Майице срииске за славистиику, 63: 79-87.

Ивић, П., Лехисте, И. (1996). Прозоgија речи и реченице у срйскохрвайском језику. Сремски Карловци - Нови Сад: Издавачка књижарница Зорана Стојановића.

Милетић, Б. (1937). Утицај реченичке мелодије на интонацију речи. Зборник у части Алексаняра Белића. Београд, 219-223.

Милетић, Б. (1952). Основи фонеииике срйской језика. Београд: Знање.

Пецо, А. (1971). Акценат речи и акценат реченице. Кюижевносӣ и језик, XVIII/1: 1-18. 


\title{
Branko M. Rakić
}

\section{INTERLANGUE PROSODIQUE: RECHERCHE EXPÉRIMENTALE SUR UN CORPUS DE PHRASES DÉCLARATIVES SIMPLES FRANÇAISES ET SERBES}

\begin{abstract}
Résumé
Dans cet article, nous abordons le sujet du transfert des caractéristiques prosodiques de la langue maternelle (serbe) dans le système prosodique de la langue cible (français). Des études contrastives de la prosodie de ces deux langues désignent ce transfert des caractérstiques accentuelles et rythmiques du serbe dans le français sous le nom de perméabilité interlinguistique. Nous tâcherons de présenter ce phénomène et de l'expliquer à la lumière d'une recherche expérimentale que nous avons effectuée à partir d'un corpus limité de phrases déclaratives simples françaises et serbes, à l'aide du logiciel de l'analyse de parole PRAAT. Dans ce contexte, nous nous pencherons brièvement sur le sujet des caractéristiques accentuelles et rythmiques du français et du serbe, ainsi que sur la question de la prosodie de la phrase déclarative simple française et serbe.

Mots-clefs: perméabilité inerlinguistique, groupe rythmique, unité accentuelle, langue française, langue serbe
\end{abstract}

